\title{
IMPLEMENTASI PENERAPAN METODE PEMBERIAN TUGAS DAPAT MENINGKATKAN PRESTASI BELAJAR IPA
}

\author{
Ni Luh Oka Anggreni
}

\author{
Sekolah Dasar Negeri 11 Sesetan \\ email : okaanggreni.oa@gmail.com
}

\begin{abstract}
Abstrak
Penelitian ini bertujuan untuk meningkatkan prestasi belajar siswa. Lokasi penelitian ini di SD Negeri 11 Sesetan dengan jumlah siswa 48 orang. Data dalam penelitian ini diperoleh dari tes prestasi belajar yang kemudian dilakukan analisis secara deskriptif. Penelitian ini dilaksanakan dalam dua siklus. Setiap siklus dilakukan berdasar tahapan: (1) menyusun rencana kegiatan, (2) melaksanakan tindakan,(3) observasi, dan (4) analisis yang dilanjutkan dengan refleksi. Hasil penelitian menunjukkan nilai IPA siswa yang diawal pembelajaran hanya mencapai rata-rata 69,06 , setelah tindakan siklus I meningkat menjadi rata-rata 78,17 dengan siswa tuntas 36 siswa dari 48 siswa. Hasil tindakan pada siklus II didapatkan prestasi belajar siswa meningkat dengan nilai rata-rata IPA mencapai 85,27 dengan semua siswa tuntas. Prosentase ketuntasan belajar pada siklus II ini telah memenuhi indikator keberhasilan yang ditetapkan yaitu $85 \%$ dan siklus dinyatakan tidak dilanjutkan. Sebagai kesimpulan bahwa metode pembelajaran Pemberian Tugas dapat dijadikan alternatif dalam meningkatkan prestasi belajar siswa.
\end{abstract}

Kata kunci: Metode Pemberian tugas, Presentasi Belajar IPA

\begin{abstract}
This study aims to improve student learning achievement. The location of this study was at SD Negeri 11 Sesetan with 48 students. The data in this study were obtained from learning achievement tests which were analyzed descriptively. This research was conducted in two cycles. Each cycle is carried out based on stages: (1) arranging an activity plan, (2) carrying out actions, (3) observations, and (4) analysis followed by reflection. The results showed the students' IPA values at the beginning of learning only reached an 69.06 average, after the action of the first cycle increased to 78.17 with students completing 36 students from 48 students. The results of the action in the second cycle showed that student learning achievement increased with the average score of IPA reaching 85.27 with all students completing. The percentage of learning completeness in this second cycle has fulfilled the determined of success indicator which is $85 \%$ and the cycle stated was not continued. In conclusion, the assignment learning method can be used as an alternative in improving student learning achievement.
\end{abstract}

Keywords: Methods of assigning assignments, Science Learning Presentations 


\section{Pendahuluan}

Pendidikan adalah suatu proses dalam rangka mempengaruhi siswa agar dapat menyesuaikan diri sebaik mungkin terhadap lingkungan dan dengan demikian akan menimbulkan perubahan dalam diri siswa yang memungkinkannya untuk berfungsi secara kuat dalam kehidupan masyarakat. Pembelajaran bertugas mengarahkan proses ini agar sasaran dari perubahan itu dapat tercapai sesuai yang diinginkan. Pengembangan kurikulum terus diupayakan untuk meningkatkan kualitas pembelajaran. Pembelajaran yang baik sebaiknya dilaksanakan secara inkuiri ilmiah untuk menumbuhkan kemampuan berpikir, bekerja dan bersikap ilmiah serta mengkomunikasikannya sebagai aspek penting kecakapan hidup. Pendidikan adalah hal terpenting bagi setiap negara untuk dapat berkembang pesat. Negara yang hebat akan menempatkan pendidikan sebagai prioritas pertamanya, karena dengan pendidikan, kemiskinan pada rakyat di negara tersebut akan dapat tergantikan menjadi kesejahteraan. Bagaimanapun, dalam perkembangannya, pendidikan di Indonesia senantiasa harus menghadapi beberapa masalah di setiap tahapnya. Masalahmasalah tersebut hanya dapat diselesaikan dengan partisipasi dari semua pihak yang terkait di dalam sistem pendidikan, seperti orangtua, guru-guru, kepala sekolah, masyarakat, dan juga peserta didik itu sendiri (Megawarti, 2015).

Pendidikan juga merupakan kegiatan yang kompleks, dan meliputi berbagai komponen yang berkaitan erat satu sama lain. Oleh sebab itu, apabila pendidikan ingin dilaksanakan secara terencana dan teratur, maka berbagai faktor yang terlibat dalam pendidikan harus dipahami terlebih dahulu. Berbagai komponen dalam sistem pendidikan, baik secara mikro maupun dalam kajian makro perlu dikenali secara mendalam sehingga komponen-komponen tersebut dapat difungsikan dan dikembangkan guna mengoptimalkan garapan pendidikan tersebut ke arah pencapaian tujuan pendidikan yang ditetapkan (Sutrisno, 2016).

Pendidikan sebuah sistem. Sebagai sistem, aktivitas pendidikan terbangun dalam beberapa komponen, yaitu pendidik, peserta didik, tujuan pendidikan, alat pendidikan, dan lingkungan pendidikan. Semua komponen yang membangun sistem pendidikan, saling berhubungan, saling tergantung, dan saling menentukan satu sama lain. Setiap komponen memiliki fungsi masing-masing dalam rangka mencapai tujuan pendidikan. Aktivitas pendidikan akan terselenggara dengan baik apabila didukung oleh komponen-komponen dimaksud. Fungsi pendidikan sebenarnya adalah menyediakan fasilitas yang dapat memungkinkan tugas pendidikan dapat berjalan lancar, baik secara struktural, maupun secara institusional. Secara struktural menuntut terwujudnya struktur organisasi yang mengatur jalannya proses kependidikan. Secara institusional mengandung implikasi bahwa proses kependidikan yang terjadi dalam struktur organisasi itu dilembagakan untuk lebih menjamin proses pendidikan itu berjalan secara konsisten dan berkesinambungan mengikuti kebutuhan dan perkembangan manusia yang cenderung ke arah tingkat kemampuan yang optimal (Saat, 2015).

Pasal 1 UU SISDIKNAS no. 20 tahun 2003 disebutkan bahwa Sistem Pendidikan Nasional adalah keseluruhan komponen pendidikan yang saling terkait secara terpadu untuk mencapai tujuan pendidikan nasional. Berangkat dari bunyi pasal ini dapat diketahui bahwa pendidikan adalah sistem yang merupakan suatu totalitas struktur yang terdiri dari komponen yang saling terkait dan secara bersama menuju kepada tercapainya tujuan (Soetarno, 2003: 2). Adapun komponen-komponen dalam pendidikan nasional antara lain adalah lingkungan, sarana-prasarana, sumberdaya, dan masyarakat. Komponen-komponen tersebut bekerja secara bersama-sama, saling terkait dan mendukung dalam mencapai tujuan pendidikan. Tujuan pendidikan nasional yang dirumuskan dalam UU SISDIKNAS adalah untuk mengembangkan potensi anak didik agar menjadi manusia yang beriman dan bertakwa kepada Tuhan Yang Maha Esa, berakhlak mulia, sehat, berilmu, cakap, kreatif, mandiri, dan menjadi warga Negara yang demokratis serta bertanggung jawab (Munirah, 2015).

Dalam upaya meningkatkan kualitas pembelajaran, guru seringkali menggunakan beberapa metode yang bervariasi. Pemilihan berbagai metode pembelajaran yang banyak jenisnya tentu harus dipertimbangkan sebelum digunakan. Pendekatan kooperatif merupakan 
salah satu metode pembelajaran yang akhir-akhir ini sering digunakan. Pendekatan ini lebih menekankan kerjasama antar siswa. Kelas dibagi menjadi kelompok-kelompok belajar yang terdiri dari siswa-siswa yang bekerjasama dalam satu perencanaan kegiatan mengajar. Setiap anggota kelompok diharapkan dapat saling bekerjasama secara sportif satu sama lain dan bertanggung jawab baik kepada dirinya sendiri maupun pada anggota dalam satu kelompok (Lie, 2008: 24).

Untuk mata pelajaran IPA yang materinya cukup kompleks dan abstrak yang berisi faktafakta, konsep-konsep, dan informasi-informasi beragam mengenai generalisasi, hukum-hukum serta prinsip-prinsip dari gejala-gejala alam, maka diperlukan kepiawaian seorang guru untuk memilih dengan tepat metode pembelajaran agar siswa dalam proses pembelajaran tertarik dan konsentrasi serta termotivasi untuk mempelajari IPA.

Kualitas belajar siswa dapat dicapai dengan menggunakan metode pembelajaran yang efektif, karena metode pembelajaran merupakan salah satu faktor yang mendukung terhadap keberhasilan siswa disamping faktor-faktor lainnya, seperti bahan pelajaran, perlengkapan pelajaran, kondisi belajar dan sebagainya. Untuk meningkatkan aktivitas dan kreativitas belajar siswa, guru dapat memberikan berbagai tugas secara bervariasi, aktivitas yang dilakukan oleh siswa selama duduk di bangku kelas hendaknya tidak hanya terpaku kepada mendengarkan ucapan guru saja, tetapi ia harus aktif mengembangkan informasi yang diterimanya dari guru

Guru merupakan faktor penentu keberhasilan pembelajaran. Usman (2002, p.9) menyebutkan bahwa proses belajar mengajar dan hasil belajar siswa sebagian besar ditentukan oleh peranan dan kinerja guru. Untuk dapat memiliki kinerja yang baik, maka seorang guru harus didukung oleh penguasaan kompetensi pedagogik maupun kompetensi sosial yang memadai. Cheng (2005, p.47) mengemukakan bahwa: "teacher performance is determined by the interaction between teacher competence, curriculum characteristics, and school organizational environment. External teacher education, school based teacher education, and pre-existing teacher characteristics can contribute to teacher competence". Kinerja guru merupakan hubungan antara kompetensi guru, karakteristik kurikulum, serta lingkungan organisasi sekolah. Pendidikan eksternal guru, pendidikan dasar guru, dan karakter guru dapat memberikan pengaruh terhadap kompetensi guru (Setiawati, 2015).

Pengalaman belajar yang bermakna sangat dibutuhkan di dalam pembelajaran IPA karena siswa dapat mencari, mencoba, menemukan, serta mengalami sendiri materi pelajaran yang berguna dan diperlukan dalam kehidupan sehari-hari. Apabila guru menguasai dan mengerti tentang hal-hal tersebut dapat diyakini bahwa prestasi belajar peserta didik pada mata pelajaran IPA dapat mencapai hasil yang maksimal. Kenyataan di kelas VI semester II SD Negeri 11 Sesetan nilai rata-rata siswa pada mata pelajaran IPA hanya mencapai 69,06 yang menunjukkan lebih rendah dari nilai KKM yang dipersyaratkan. Angka KKM yang dicapai siswa hanya $58 \%$ atau hanya sekitar 28 siswa yang mampu tuntas pada mata pelajaran IPA. Untuk itu penelitian ini dilakukan guna dapat meningkatkan prestasi belajar IPA siswa kelas VI semester II di SD Negeri 11 Sesetan tahun pelajaran 2017/2018 melaui optimalisasi penggunaan metode pemberian tugas dalam pembelajaran.

\section{Metode}

Penelitian ini merupakan Penelitian Tindakan Kelas (PTK) yang dilakukan di SD Negeri 11 Sesetan dari bulan Januari - Maret 2018 dengan subyek penelitian adalah siswa kelas VI semester II SD Negeri 11 sesetan tahun pelajaran 2017/2018, dan sebagai obyek penelitian adalah peningkatan prestasi belajar IPA. Rancangan penelitian mengikuti rancangan Mc. Kernan seperti terlihat pada gambar di bawah ini. 


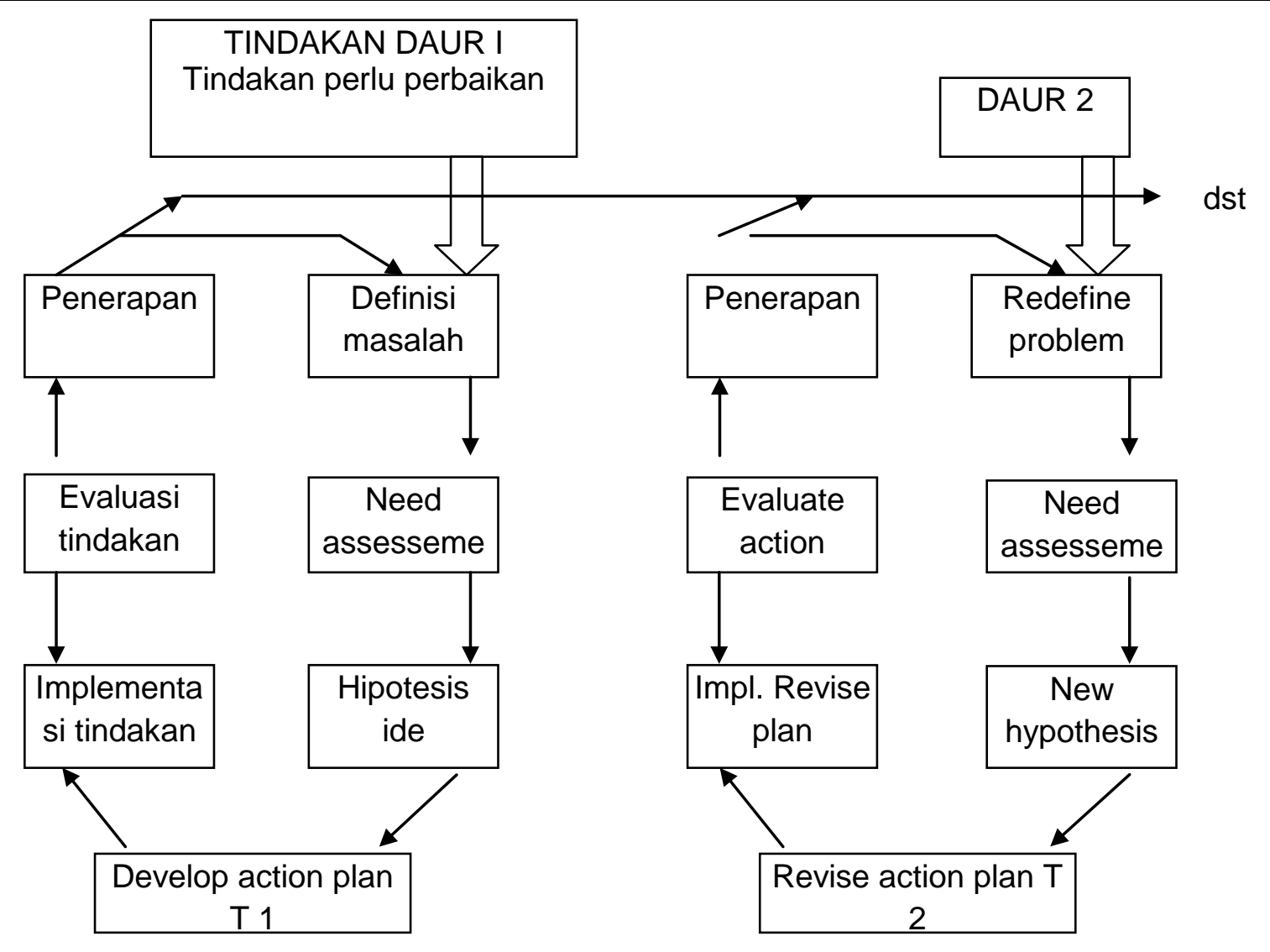

Gambar 1. Penelitian Tindakan Model Mc. Kernan, 1991 (dalam Sukidin, Basrowi, Suranto, 2002).

Tindakan siklus I dilakukan definisi masalah dilanjutkan dengan pelaksanaan di lapangan, dirumuskan hipotesisnya, dikembangkan hipotesis tersebut, diimplementasikan, dievauasi dari hasil yang didapat dan evaluasi diterapkan. Langkah-langkah pada daur II atau siklus II sama dengan yang di siklus I yaitu dimulai dengan adanya suatu permasalahan yang baru, didefinisikan masalahnya, dibuat hipotesisnya direvisi, selanjutnya dilakukan implementasi di lapangan, dievaluasi, kemudian hasil yang didapat merupakan penerapan baru apabila masih ada masalah. Penelitian ini merupakan Penelitian Tindakan Kelas maka prosedur penelitian ini sesuai dengan prosedur penelitian tindakan kelas yang dilakukan dalam suatu proses berdaur/bersiklus. Setiap siklus terdiri dari perencanaan, tindakan, observasi dan refleksi. Rancangan dilakukan bersama antara peneliti yang akan melakukan tindakan dengan guru lain yang akan mengamati proses jalannya tindakan. Hal tersebut untuk mengurangi unsur subjektivitas pengamat serta mutu kecermatan pengamatan yang dilakukan. Pelaksanaan tindakan adalah kegiatan pembelajaran yang dilakukan peneliti menerapkan metode, model, strategi yang digunakan. Rancangan tindakan tersebut sebelumnya telah dilatih untuk dapat diterapkan di dalam kelas sesuai skenarionya. Skenario dari tindakan diupayakan dilaksanakan dengan baik dan wajar. Pengamatan dilakukan pada waktu tindakan sedang berjalan, jadi, keduanya berlangsung dalam waktu yang sama. Tahap ini sebenarnya berjalan bersamaan dengan saat pelaksanaan. Pada tahap ini, guru yang bertindak sebagai peneliti melakukan pengamatan dan mencatat semua hal yang diperlukan dan terjadi selama pelaksanaan tindakan berlangsung. Pengumpulan data ini dilakukan dengan menggunakan tes prestasi belajar yang telah tersusun, termasuk juga pengmatan secara cermat pelaksanaan skenario tindakan dari waktu ke waktu serta dampaknya terhadap proses dan hasil belajar anak. Refleksi dalam PTK mencakup analisis, sintesis, dan penilaian terhadap hasil pengamatan atas tindakan yang dilakukan. Jika terdapat masalah dari proses refleksi maka dilakukan proses pengkajian ulang melalui siklus berikutnya yang meliputi kegiatan: perencanaan ulang, 
tindakan ulang, dan pengamatan ulang shingga permasalahan dapat teratasi. Pada tahapan ini dimaksudkan untuk mengkaji secara menyeluruh tindakan yang telah dilakukan, berdasarkan data terkumpul, kemudian dilakukan evaluasi guna menyempurnakan tindakan berikutnya.

Instrumen yang digunakan pada penelitian ini adalah tes prestasi belajar. Pengumpulan data dilakukan dengan menggunakan tes prestasi belajar yang telah tersusun, termasuk juga pengamatan secara cermat pelaksanaan skenario tindakan dari waktu ke waktu serta dampaknya terhadap proses dan hasil belajar siswa. Refleksi dalam PTK mencakup analisis, sintesis, dan penilaian terhadap hasil pengamatan atas tindakan yang dilakukan. Jika terdapat masalah dari proses refleksi maka dilakukan proses pengkajian ulang melalui siklus berikutnya yang meliputi kegiatan: perencanaan ulang, tindakan ulang, dan pengamatan ulang shingga permasalahan dapat teratasi. Pada tahapan ini dimaksudkan untuk mengkaji secara menyeluruh tindakan yang telah dilakukan, berdasarkan data yang telah terkumpul, kemudian dilakukan evaluasi guna menyempurnakan tindakan berikutnya. Data yang terkumpul kemudian dianalisis secara statistik dengan metode analisis statistik deskriptif kuantitatif. Untuk data kuantitatif dianalisis dengan mencari mean, median, modus, serta menyajikan semua data dalam tabel untuk selanjutnya dibuat gambar grafiknya. Hasil perhitungan rata-rata prestasi belajar siswa dalam mata pelajaran IPA kemudian dibandingkan dengan tabel Penilaian Acuan Patokan (PAP) skala lima. Indikator keberhasilan penelitian menggunakan kriteria yang digunakan untuk menunjukkan keberhasilan tindakan ini yaitu terjadinya perubahan/peningkatan prestasi belajar IPA, berupa peningkatan prestasi belajar siswa berada diatas KKM yang ditetapkan sekolah yaitu lebih dari atau sama dengan 72 dengan ketuntasan belajar secara klasikal $85 \%$.

\section{Hasil Dan Pembahasan}

Hasil Nilai rata-rata bidang studi IPA kelas VI semester II SD Negeri 11 Sesetan pada awal semester baru mencapai 69,06. Nilai ini masih jauh dari ketuntasan belajar yang dipersyaratkan. Dilakukan upaya perbaikan melalui Rencana Pelaksanaan Pembelajaran (RPP) siklus I dan II. Peneliti membuat Rencana Pelaksanaan Pembelajaran yang akan dilaksanakan dengan metode Pembagian Tugas. Dalam pelaksanaan pembelajaran inti, teori-teori pembelajaran Pembagian Tugas dimasukkan mengikuti skenario pembelajaran dengan pembentukan kelompok yang terdiri 4-6 siswa yang merupakan kelompok yang mampu bersinergi guna mencapai tujuan pembelajaran. Kerjasama yang kolaboratif serta bersinergi yang dapat mengantarkan kemajuan belajar yang bermakna bagi siswa. Dengan maksud memberdayakan seluruh kemampuan dan potensi yang ada, rancangan belajar yang dinamis, guru mengupayakan bermacam-macam interaksi baik dalam maupun antar kelompok, mengupayakan agar pembelajaran menjadi bermakna, dan efektif. Berdasarkan hasil awal kemampuan siswa kelas VI SD Negeri 11 Sesetan dalam bidang studi IPA dimana sebanyak $42 \%$ masih belum mampu mencapai nilai $\geq 72$, maka peneliti merencanakan kegiatan yang lebih intensif seperti berkonsultasi dengan teman-teman guru dan kepala sekolah tentang persiapan pelaksanaan pembelajaran menggunakan metode pembelajaran Pembagian Tugas. Meminta kepada teman-teman guru bidang studi sejenis dan kepala sekolah sebagai mitra kesejawatan dalam pelaksanaan RPP ikut serta mengawasi jalannya proses pembelajaran yang sudah direncanakan. Menentukan yang menjadi prinsip supervisi teknik kunjungan kelas. Memperbanyak jumlah/frekuensi kunjungan kelas dalam siklus berikutnya sehingga kedekatan supervisor dengan guru dan siswa akan terjalin dengan baik. Merencanakan bahan pelajaran dan merumuskan tujuan. Menentukan bahan pelajaran, dengan cara menyesuaikan dengan silabus yang berlaku dan penjabarannya dengan cukup baik. Memilih dan mengorganisaasikan materi, media, dan sumber belajar serta merancang 
skenario pembelajaran. Skenario pembelajaran disesuikan dengan tujuan, materi dan tingkat perkembangan siswa, diupayakan variasi dalam penyampaian.

Sebagai upaya Trianggulasi, pada pelaksanaan pembelajaran Pembagian Tugas ini peneliti mengajak seorang guru ke kelas untuk memantau kebenaran pelaksanaan pembelajaran Pembagian Tugas. Guru sudah diberitahu sebelumnya tentang kebenaran model pembelajaran Pembagian Tugas sehingga memiliki kemampuan untuk mengamati proses.

Analisis kuantitatif prestasi belajar siswa kelas VI Semester II SD Negeri 11 Sesetan bidang studi IPA pada siklus I menunjukkan bahwa dari tes yang dilakukan terhadap 48 siswa kelas VI SD Negeri 11 Sesetan siklus 1 didapatkan hasil sebagai berikut : Mean (rata-rata) nilai IPA adalah 78,17. Median (titik tengah) adalah 80. Modus (angka yang paling banyak muncul) adalah80. Nilai minimum adalah 50 sedangkan nilai maksimum 90 . Berdasarkan nilai KKM (Kriteria Ketuntasan Minimal), sebanyak 36 ( $75 \%$ ) siswa telah mampu mencapai KKM seperti terlihat pada gambar di bawah

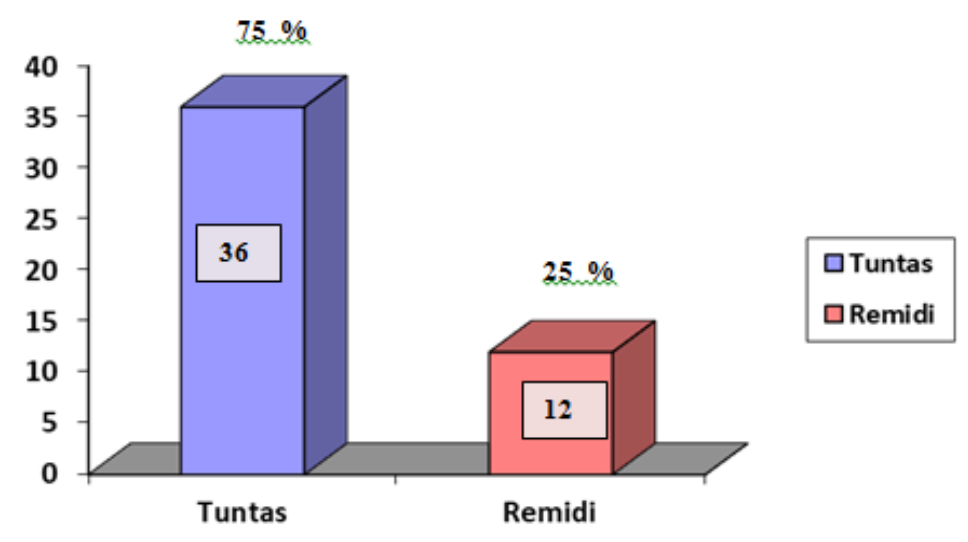

Gambar 2. Klasifikasi Siswa Kelas VI SD Negeri 11 Sesetan Berdasarkan Pencapaian Nilai KKM IPA siklus 1

Berdasarkan Hasil tes prestasi belajar yang merupakan tes tertulis mengupayakan siswa untuk betul-betul dapat memahami apa yang sudah dipelajari. Nilai IPA rata-rata siswa di siklus I adalah sebesar 78,17 jauh lebih tinggi dibandingkan nilai rata-rata pada siklus awal yang hanya mencapai 69,06 . Adanya peningkatan nilai IPA rata-rata sebesar $13,19 \%$ menunjukkan bahwa siswa sudah mulai menguasai materi yang diajarkan walaupun belum begitu sempurna. Jumlah siswa yang bisa mencapai KKM sebanyak 36 atau $75 \%$ jauh lebih tinggi dari pada jumlah siswa yang mencapai nilai KKM pada siklus awal yang hanya 28 orang atau $58 \%$.

Hasil tes prestasi belajar di siklus I telah menemukan efek utama bahwa penggunaan metode pembelajaran Pembagian Tugas akan berpengaruh terhadap prestasi belajar siswa. Hal ini sesuai dengan hasil meta analisis metode pembelajaran yang dilakukan oleh Soedomo (dalam Puger, 2004) yang menyatakan bahwa metode pembelajaran yang diterapkan oleh seorang guru berpengaruh terhadap prestasi belajar siswanya.

Seperti telah diketahui bersama bahwasannya model pembelajaran Pembagian Tugas menitikberatkan pembelajaran kelompok heterogen kemampuan belajarnya juga heterogen termasuk status sosial maupun etnis. Untuk penyelesaian kesulitan yang ada maka penggunaan model ini dapat membantu siswa untuk berkreasi, bertindak aktif, bertukar pikiran, mengeluarkan pendapat, bertanya, berdiskusi, berargumentasi, bertukar informasi dan memecahkan masalah yang ada. Hal inilah yang menuntun siswa berpikir lebih tajam, lebih kreatif dan kritis sehingga mampu untuk memecahkan masalah-masalah kehidupan yang nanti efek selanjutnya adalah para siswa akan dapat memahami dan meresapi mata pelajaran lebih jauh.

Kendala yang masih tersisa yang perlu dibahas adalah prestasi belajar yang dicapai pada siklus I ini belum memenuhi harapan sesuai dengan kriteria keberhasilan penelitian yang 
diusulkan di sekolah ini yaitu nilai ketuntasan minimal mencapai minimal $85 \%$. Baru $75 \%$ siswa yang mampu mencapai nilai ketuntasan minimal (nilai minimal 72). Oleh karenanya upaya perbaikan lebih lanjut masih perlu diupayakan sehingga perlu dilakukan perencanaan yang lebih matang untuk siklus selanjutnya.

Dengan melihat semua hasil yang didapat pada siklus I, baik refleksi data kualitatif maupun refleksi data kuantitatif, maka dilakukan perbaikan- perbaikan pada siklus II. Perbaikan tersebut meliputi merencanakan kunjungan kelas bersama-sama guru dan kepala sekolah sebagai upaya trianggulasi data. Untuk ini peneliti berkonsultasi dengan kepala sekolah, minta kesediaannya untuk ikut proses pembelajaran yang dilakukan. Inovasi ini dilakukan agar peneliti dapat berupaya lebih maksimal untuk melaksanakan pembelajaran yang lebih baik dan lebih berkualitas. Disamping itu bersama guru pemantau dirancang skenario penerapan pembelajaran dengan melihat kekurangan-kekurangan yang ada pada siklus I melalui identifikasi hal-hal yang bisa dilakukan untuk peningkatan pembelajaran. Pada pelaksanaan tindakan, semua persiapan yang telah dibuat dibawa termasuk instrumen pengamatan observasi keaktifan belajar, instrumen observasi dan tes prestasi belajar. Pada pembelajaran inti peneliti melaksanakan explorasi, elaborasi dan konfirmasi dengan banyak bertanya, banyak memotivasi keaktifan kelompok dengan mendorong siswa pintar dalam kelompok untuk memberi kontribusi dan berusaha mendorong keaktifan teman-temannya.

Dari tes yang dilakukan terhadap 48 siswa kelas VI SD Negeri 11 Sesetan pada siklus 2 didapatkan hasil sebagai berikut : Mean (rata-rata) adalah 85,27. Median (titik tengah) 85. Modus (angka yang paling banyak muncul) adalah 78. Nilai minimum adalah 75 dengan nilai maksimum 90. Berdasarkan nilai KKM (Kriteria Ketuntasan Minimal), semua siswa (100 \%) telah mampu mencapai KKM (nilai 72) seperti terlihat pada gambar di bawah

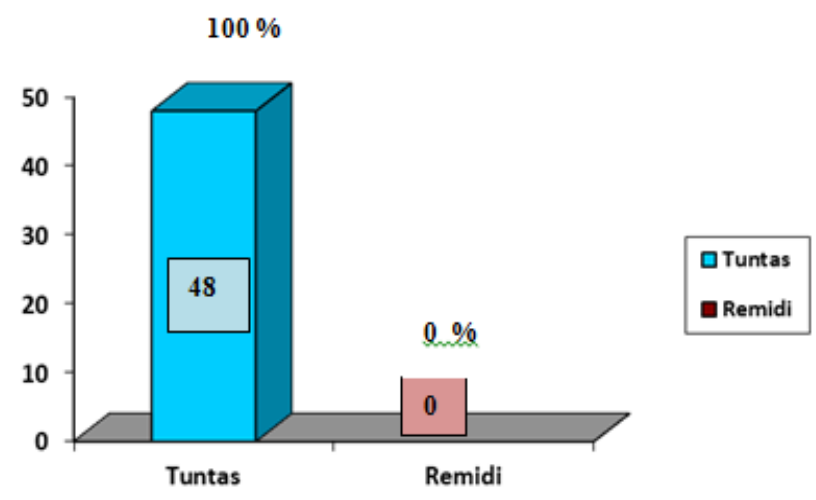

\section{Gambar 3. Klasifikasi Siswa Kelas VI SD Negeri 11 Sesetan Berdasarkan Pencapaian Nilai KKM IPA siklus 2.}

Hasil yang diperoleh dari tes prestasi belajar di siklus II menunjukkan bahwa kemampuan siswa dalam mengikuti pelajaran sudah cukup baik. Ini terbukti dari rata-rata nilai siswa mencapai 85,27 dengan semua siswa (100\%) telah mampu mencapai KKM. Hasil ini menunjukkan bahwa model pembelajaran Pembagian Tugas telah berhasil meningkatkan kemampuan siswa menempa ilmu sesuai harapan. Model pembelajaran Pembagian Tugas merupakan model yang cocok bagi siswa dimana mereka diharapkan memiliki kemampuan bervariasi, berbicara banyak, mengeluarkan pendapat secara lugas, bertukar pikiran. Mengingat penggunaan metode ini adalah untuk memupuk kemampuan berbicara siswa, rasa ingin tahu siswa, kemampuan lebih untuk berprestasi, memupuk kesenangan yang tinggi dalam belajar, mengupayakan kemampuan yang tinggi untuk siswa dapat berinteraksi dengan materi, berinteraksi dengan sesama siswa dan juga dengan guru.

Hasil penelitian ini ternyata telah memberi efek utama bahwa model yang diterapkan dalam proses pembelajaran berpengaruh secara signifikan terhadap prestasi belajar siswa. Temuan ini membuktikan bahwa guru sudah tepat memilih metode dalam melaksanakan 
proses pembelajaran karena pemilihan metode merupakan hal yang tidak boleh dikesampingkan. Hal ini sejalan pula dengan temuan-temuan peneliti lain seperti yang dilakukan oleh Inten (2004) dan Puger (2004) yang pada dasarnya menyatakan bahwa metode pembelajaran yang diterapkan berpengaruh terhadap prestasi belajar siswa.

Setelah dibandingkan nilai awal, nilai siklus I dan nilai siklus II, terjadi kenaikan yang signifikan, yaitu dari rata-rata nilai awal 69,06 naik di siklus I menjadi 78,17 dan di siklus II naik lagi menjadi 85,27. Kenaikan ini tentu besar maknanya karena kenaikan nilai ini adalah dari upaya-upaya yang maksimal yang dilaksanakan peneliti demi peningkatan mutu pendidikan dan kemajuan pendidikan khususnya di kelas VI semeste II SD Negeri 11 Sesetan Tahun Pelajaran 2017 / 2018.

\section{Simpulan dan Saran}

Berdasarkan Model pembelajaran Pembagian Tugas dapat memenuhi tujuan penelitian ini untuk meningkatkan prestasi belajar siswa SD Negeri 11 Sesetan khususnya dalam bidang pelajaran IPA. Hal ini ditandai dengan didapatkannya peningkatan nilai rata-rata IPA yang dicapai siswa yaitu dari 69,06 di awal pembelajaran menjadi 78,17 pada siklus I dan 85,27 pada siklus II. Disamping itu terjadi peningkatan jumlah siswa yang mencapai nilai ketuntasan minimal. Dari data awal yang tuntas hanya $58 \%$ naik menjadi $75 \%$ pada siklus I dan pada siklus II semua siswa telah mampu mencapai nilai ketuntasan minimal.

\section{Daftar Rujukan}

Arikunto, Suharsimi. 1990. Prosedur Penelitian Suatu Pendekatan Praktek. Jakarta: Rineka Cipta.

Arikunto, Suharsimi; Suhardjono; Supardi. 2006. Penelitian Tindakan Kelas. Jakarta: PT Bumi Aksara.

Djamarah, Syaiful Bahri dan Aswan Zain. 2002. Strategi Belajar Mengajar. Jakarta: Rineka Cipta.

Gagne, Robert M. 1985. The Conditions of Learning. Third Edition. New York: Holt, Reinhart and Winston.

Puger, I Gusti Ngurah. 2004. Belajar Kooperatif. Diktat Perkuliahan Mahasiswa Unipas

Megwati, Priarti. 2015. Meretas Permasalahan Pendidikan Di Indonesia . Jurnal Formatif 2(3): 227-234 ISSN: 2088-351X

Mulyani Sumantri \& Johar Permana. 2001.Strategi Belajar Mengajar. Bandung: CV Maulana.

Munirah. 2015. Sistem Pendidikan Di Indonesia: Antara Keinginan Dan Realita . Jurnal Auladuna, Vol. 2 No. 2 Desember 2015: 233-245

Oemar Hamalik. 2003. Proses Belajar Mengajar. Bumi Aksara: Jakarta.

Setiawati, Linda. 2015. Faktor-Faktor Yang Mempengaruhi Prestasi Belajar Praktik Kejuruan Siswa Smk Program Studi Keahlian Teknik Komputer Dan Informatika . Jurnal Pendidikan Vokasi, Vol 5, Nomor 3, November 2015

Sudjana, Nana. 2002. Penilaian Hasil Proses Belajar Mengajar. Bandung: PT Remaja Rosdakarya. 
Sukidin, Basrowi, Suranto. 2002. Menajemen Penelitian Tindakan Kelas. Penerbti: Insan Cendekia ISBN: 9799048334.

Sukmadinata, Nana. 2005. Landasan Psikologi Proses Pendidikan. Bandung: PT Rosda Karya.

Saat, Sulaiman. 2015. Faktor-Faktor Determinan Dalam Pendidikan (Studi Tentang Makna Dan Kedudukannya Dalam Pendidikan) . Jurnal Al-Ta'dib Vol. 8 No. 2, Juli-Desember 2015

Sutrisno. 2016. Berbagai Pendekatan Dalam Pendidikan Nilai Dan Pendidikan Kewarganegaraan . Jurnal Dimensi Pendidikan dan Pembelajaran Vol.5 Januari 2016

Tim Penyusun, 2005, Kamus Besar Bahasa Indonesia, Jakarta: Balai Pustaka.

Udin, S.W. 1997. Teori Belajar dan Model-Model Pembelajaran. Depdikbud: Jakarta. 